\title{
Permasalahan dan Penataan Pendidikan Islam Menuju Pendidikan yang Bermutu
}

\author{
Hujair A. H. Sanaky
}

\begin{abstract}
Abstrak
Mutu pendidikan merupakan hal yang harus diperhatikan dan diupayakan untuk dicapai, sebab pendidikan akan menjadi sia-sia bila mutu proses dan lulusannya rendah. Lebih parah dan menyedihkan lagi jika out put pendidikannya menambah beban masyarakat, keluarga, dan negaranya. Masyarakat dan berbagai lembaga pendidikan Islam berkeinginan untuk menjadikan pendidikan Islam sebagai salah satu pendidikan alternatif. Pemikiran semacam ini memerlukan paradigma baru untuk meningkatkan kualitan pendidikannya, diperlukan penataan program pendidikan Islam mulai dari visi, misi, tujuan, kurikulum dan materi pembelajaran, strategi dan metode, manajemen dan kepemimpinan yang berkualitas, dana, dan dukungan pemerintah dan penerimaan masyarakat terhadap prodak pendidikan Islam.
\end{abstract}

Kata Kunci: Pendidikan Islam yang mutu dan unggul

\section{A. Pendahuluan}

Reformasi di Indonesia seakan menjadi cahaya impian yang akan memberikan banyak perubahan kehidupan bagi bangsa ini, khusunya pada sektor pendidikan. Akan tetapi, apa yang terjadi kemudian, justru pendidikan di bumi Indonesia semakin menjadi problem baru, yakni lahirnya ambiguisitas dalam wilyah pendidikan yang terus berjalan di Indonesia. Kondisi ironis pendidikan tersebut adalah mengenai goal setting yang ingin dicapai sistem

${ }^{1}$ Dosen Tetap Fakultas Ilmu Agama Islam Universitas Islam Indonesia Yogyakarta. 
pendidikan. Gambaran riil adalah lahirnya tipe mechanic student di mana setiap peserta didik sudah diposisikan pada orientasi pasar sehingga pendidikan bukan lagi berbasis keilmuan dan kebutuhan bakat peserta didik. Selain itu, munculnya mitologi ruang pendidikan yang dikukuhkan dengan ritual pendidikan. Artinya, anak bangsa dihadapkan pada ritual kompetisi, pemilihan sekolah favorit, penyuguhan uang "persembahan", pemakaian seragam baru, pembelian "ramuan-ramuan" buku-buku paket baru, dan segudang ritual lain. Muncul, ambiguisitas kebijakan pemerintah yang sebenarnya sebagai pengelola potensi anak bangsa, namun pemerintah justru menjadi penjaga mitos pendidikan. Pemerintah dengan sangat percaya diri memilih posisi lebih berpihak pada kelangan elite, maka muncul adigium lelang pendidikan (Ahmad Baharuddin, 2007 : 7).

Permasalahan pendidikan di Indonesia secara umum, diidentifikasi dalam empat krisis pokok, yaitu menyangkut masalah: kualitas, relevansi, elitisme, dan manajemen. Berbagai indikator kuantitatif dikemukakan berkenaan dengan keempat masalah di atas, antara lain analisis komparatif yang membandingkan situasi pendidikan antara negara di kawasan Asia. Keempat masalah tersebut merupakan masalah besar, mendasar, dan multidimensional, sehingga sulit dicari ujung pangkal pemecahannya (Tilaar, 1991). Permasalahan ini terjadi pada pendidikan secara umum di Indonesia, termasuk pendidikan Islam yang dinilai justru lebih besar problematikanya.

Pendidikan Islam juga dihadapkan dan terperangkap pada persoalan yang sama, bahkan apabila diamati dan kemudian disimpulkan pendidikan Islam terkukung dalam kemunduran, keterbelakangan, ketidak berdayaan, dan kemiskinan, sebagaimana pula yang dialami oleh sebagian besar negara dan masyarakat Islam dibandingkan dengan mereka yang non Islam. Katakan saja, pendidikan Islam terjebak dalam lingkaran yang tak kunjung selesai yaitu persoalan tuntutan kualitas, relevansi dengan kebutuhan, perubahan zaman, dan bahkan pendidikan apabila diberi "embel-embel Islam", dianggap berkonotasi kemunduran dan keterbelakangan, meskipun sekarang secara berangsur-angsur banyak diantara lembaga pendidikan Islam yang telah menunjukkan kemajuan (Soeroyo, 1991: 77). Tetapi pendidikan Islam dipandang selalu berada pada posisi deretan kedua atau posisi marginal dalam sistem pendidikan nasional di Indonesia. Dalam UndangUndang sistem pendidikan nasional menyebutkan pendidikan Islam merupakan sub-sistem pendidikan nasional. Jadi sistem pendidikan 
itu satu yaitu memanusiakan manusia, tetapi pendidikan memiliki banyak wajah, sifat, jenis dan jenjang [pendidikan keluarga, sekolah, masyarakat, pondok pesantren, madrasah, program diploma, sekolah tinggi, institusi, universitas, dsb], dan hakekat pendidikan adalah mengembangkan harkat dan martabat manusia, memanusiakan manusia agar benar-benar mampu menjadi khalifah (Mastuhu, 2003).

Pendidikan Islam menjadi satu dalam sistem pendidikan nasional, tetapi predikat keterbelakangan dan kemunduran tetap melekat padanya, bahkan pendidikan Islam sering "dinobatkan" hanya untuk kepentingan orang-orang yang tidak mampu atau miskin, memproduk orang yang eksklusif, fanatik, dan bahkan pada tingkah yang sangat menyedihkan yaitu "terorisme-pun" dianggap berasal dari lembaga pendidikan Islam, karena pada kenyataannya beberapa lembaga pendidikan Islam "dianggap" sebagai tempat berasalnya kelompok tersebut. Walaupun "anggapan" ini keliru dan dapat ditolak, sebab tidak ada lembaga-lembaga pendidikan Islam manapun yang bertujuan untuk memproduk atau mencetak kelompok-kelompok orang seperti itu. Tetapi realitas di masyakarat banyak perilaku kekerasan yang mengatasnamakan Islam. Apakah ada sesuatu yang salah dalam sistem, proses, dan orientasi pendidikan Islam.

Hal ini, merupakan suatu kenyataan yang selama ini dihadapi oleh lembaga pendidikan Islam di Indonesia. Olah karena itu, muncul tuntutan masyarakat sebagai pengguna pendidikan Islam agar ada upaya penataan dan modernisasi sistem dan proses pendidikan Islam aga menjadi pendidikan yang bermutu, relevan, dan mampu menjawab perubahan untuk meningkatkan kualitas manusia Indonesia. Dengan demikian, penataan model, sistem dan proses pendidikan Islam di Indonesia merupakan suatu yang tidak terelakkan, untuk menjawab permintaan dari arus globalisasi yang tidak dapat dibendung lagi (Proposal Jurnal Pendidikan Islam PAI FIAI UII : 2008) dan menjawab predikat keterbelakangan dan kemunduran yang selalu melekat pada pendidikan Islam. Hemat penulis, strategi pengembangan pendidikan Islam hendaknya dipilih dari kegiatan pendidikan yang paling mendesak, berposisi senteral yang akan menjadi modal dasar untuk usaha penataan dan pengembangan selanjutnya. Katakan saja, perubahan paradigama, visi, misi, tujuan, dana, dan sampai pada program-program pendidikan yang sesuai dengan tuntutan perubahan kehidupan dalam negeri ini, seperti: perubahan kurikulum pendidikan secara terarah dan kontinu agar dapat mengikuti perubahan ilmu pengetahuan dan teknologi. 


\section{B. Penataan Pendidikan Islam}

Pendidikan Islam di Indonesia merupakan salah satu variasi dari konfigurasi sistem pendidikan nasional. Tetapi pada kenyataannya pendidikan Islam tidak memiliki kesempatan yang luas untuk bersaing dalam membangun umat yang besar ini. Terasa janggal dan lucu, dalam komunitas masyarakat muslim terbesar, pendidikan Islam tidak mendapat kesempatan yang luas untuk bersaing dalam membangun umat yang besar ini. Selain itu, paradigma birokrasi tentang pendidikan Islam selama ini lebih didominasi pendekatan sektoral dan bukan pendekatan fungsional, sebab pendidikan Islam tidak dianggap bagian dari sektor pendidikan lantaran urusannya tidak di bawah Depdiknas (Abdul Aziz, Kompas, 18 Maret 2004) Maka, perhatian pemerintah yang dicurahkan pada pendidikan Islam sangatlah kecil porsinya, padahal masyarakat Indonesia selalu diharapkan agar tetap berada dalam lingkaran masyarakat yang sosialistis religius (Muslih Usa: 1991: 11). Dari sinilah timbul pertanyaan, bagaimanakah kemampuan pendidikan Islam di Indonesia untuk menata, mengatasi, dan menyelesaikan problemproblem yang dihadapi menuju pendidikan bermutu dan unggul.

Langkah awal yang diperhatikan untuk melakukan penataan pendidikan Islam, harus menganalisis dari aspek kekuatan, kelemahan, kesempatan, dan ancaman. Pertama, pendidikan Islam [pesantren, madrasah, sekolah yang bercirikan Islam, dan perguruan tinggi] lebih besar $>80 \%$ dikelola oleh swasta. Dalam pengelolaannya lebih percaya dan hormat pada ulama, percaya bahwa guru mengajarkan sesuatu yang benar, panggilan agama, ibadah, ikhlas, murah, merakyat. Hal ini merupakan kekuatan [strengt] dalam pengelolaan pendidikan Islam. Kedua, kelemahan [weakness], bahwa pendidikan Islam posisinya lemah, tidak profesional hampir disemua sektor dan komponennya, stress, terombang-ambing antara jati dirinya, apakah ikut model sekolah umum atau antara ikut Diknas dan Depag. Belum ada sistem yang mantap dalam pengembangan model pendidikan agama dan pendidikan keagamaan. Ketiga, kesempatan [opportunities], bahwa dalam UU No.20 Th. 2003 memberi kesempatan atau momentum pengembangan pendidikan agama dan keagamaan. Pendidikan Islam diakui sama dengan pendidikan yang lain. Keempat, ancaman [treat], bahwa banyak lembaga pendidikan lain yang lebih tangguh dan berkualitas, Ilmu dan teknologi yang berkembang sangat pesat berlum terkejar oleh pendidikan Islam, pendidikan Islam kehilangan jati dirinya, pendidikan Islam selalu menjadi warga kelas dua, 
tercabut dari akar budaya komunitas muslimnya. Dalam perspektif pendidikan, mungkin akan bertanya mampukah kita menciptakan dan mengembangkan sistem pendidikan Islam yang menghasilkan lulusan-lusan yang "mampu memilih" tanpa kehilangan peluang dan jati dirinya? (Mastuhu, 2003: 10).

Memang samapi sekarang, perlakuan pemerintah dan masyarakat terhadap pendidikan Islam masih tetap sama, diskriminatif. Sikap inilah yang menyebabkan pendidikan Islam sampai detik ini terpinggirkan. Terpinggirnya pendidikan Islam dari persaingan sesungguhnya dikarenakan dua faktor, yaitu faktor internal dan eksternal. Faktor internal, pertama, meliputi manajemen pendidikan Islam yang pada umumnya belum mampu menyelenggarakan pembelajaran dan pengelolaan pendidikan yang efektif dan berkualitas. Hal ini tercermin dari kalah bersaing dengan sekolah-sekolah yang berada di bawah pembinaan Departemen Pendidikan Nasional [Diknas] yang umumnya dikelola secara modern. Kedua, faktor kompensasi profesional guru yang masih sangat rendah. Para guru yang merupakan unsur terpenting dalam kegiatan belajarmengajar, umumnya lemah dalam penguasaan materi bidang studi, terutama menyangkut bidang studi umum, ketrampilan mengajar, manajemen keles, dan motivasi mengajar. Hal ini terjadi karena sistem pendidikan Islam kurang kondusif bagi pengembangan kompetensi profesional guru. Ketiga, adalah faktor kepemimpinan, artinya tidak sedikit kepala-kepala madrasah yang tidak memiliki visi, dan misi untuk mau ke mana pendidikan akan dibawa dan dikembangkan. Kepala madrasah seharusnya merupakan simbol keunggulan dalam kepemimpinan, moral, intelektual dan profesional dalam lingkungan lembaga pendidikan formal, ternyata sulit ditemukan di lapangan pendidikan Islam. Pimpinan pendidikan Islam bukan hanya sering kurang memiliki kemampuan dalam membangun komunikasi internal dengan para guru, melainkan juga lemah dalam komunikasi dengan masyarakat, orang tua, dan pengguna pendidikan untuk kepentingan penyelenggaraan pendidikan yang berkualitas. Biasanya pendekatan yang digunakan adalah pendekatan birokratis daripada pendekatan kolegial profesional. Mengelola pendidikan bukan berdasar pertimbangan profesional, melainkan pendekatan like and dislike (Mahfudh Djunaidi, 2005), dengan tidak memiliki visi dan misi yang jelas.

Faktor eksternal yang dihadapi pendidikan Islam adalah pertama, adanya perlakuan diskriminatif pemerintah terhadap pendidikan Islam. Pemerintah selama ini cenderung menganggap dan memperlakukan pendidikan Islam sebagai anak tiri, khususnya 
soal dana dan persoalan lain. Katakan saja, alokasi dana yang diberikan pemerintah sangat jauh perbedaannya dengan pendidikan yang berada di lingkungan Diknas (Mahfudh Djunaidi, 2005). Maka, terlepas itu semua, apakah itu urusan Depag atau Depdiknas, mestinya alokasi anggaran negara pada pendidikan Islam tidak terjadi kesenjangan, toh pendidikan Islam juga bermisi untuk mencerdaskan bangsa, sebagaimana juga misi yang diemban oleh pendidikan umum. Faktor kedua, dapat dikatakan bahwa paradigma birokrasi tentang pendidikan Islam selama ini lebih didominasi oleh pendekatan sektoral dan bukan pendekatan fungsional. Pendidikan Islam tidak dianggap bagian dari sektor pendidikan, lantaran urusannya tidak di bawah Depdiknas. Beberapa indikator yang menunjukkan kesenjangan ini yaitu mulai dari tingkat ketersediaan tenaga guru, status guru, kondisi ruang belajar, tingkat pembiayaan [unit cost] siswa, hingga tidak adanya standardisasi mutu pendidikan Islam, karena urusan pendidikan Islam tidak berada di bawah Depdiknas (Abdul Aziz, Kompas, 2005), dan lebih tragis lagi adalah sikap diskriminatif terhadap prodak atau lulusan pendidikan Islam. Faktor ketiga, adalah adanya diskriminasi masyarakat terhadap pendidikan Islam. Secara jujur harus diakui, bahwa masyarakat selama ini cenderung acuh terhadap proses pendidikan di madrasah atau sekolah-sekolah Islam. Rata-rata memandang pendidikan Islam adalah pendidikan nomor dua dan biasanya bila menyekolahkan anaknya di lembaga pendidikan Islam merupakan alternatif terakhir setelah tidak dapat diterima di lembaga pendidikan di lingkungan Diknas (M Dahriman, 2005).

Diakui perkembangan pendidikan Islam pada akhir-akhir ini secara berangsur-angsur mulai terasa kemajuannya, hal ini terbukti dengan berdirinya lembaga-lembaga pendidikan Islam dan beberapa model pendidikan yang ditawarkan, yang menunjukan harapan untuk mampu bersaing. Tetapi masih banyak yang memerlukan penataan. Maka untuk menuju pendidikan yang bermutu dan unggul, pendidikan Islam hendaknya berupaya maksimal untuk membenahi dan melakukan penataan kembali terhadap masalah internalnya, seperti persoalan manajemen, kemampuan kepemimpinan, kompetensi dan profesional guru. Manajemen pendidikan yang bersifat klasik harus ditinggalkan dan berfokus ke manajemen berbasis mutu. Manajemen memiliki visi, missi, goals dan strategi yang akan diterapkan dalam mencapai tujuan. Namun visi, missi dan goals pun jangan hanya akan menjadi tumpukan berkas perencanaan yang tidak dapat diwujudkan secara nyata apabila kita tidak memiliki rencana strategi yang baik dan tepat (M. Dahriman, 2005). 
Dari paparan di atas, menurut hemat penulis bahwa inovasi atau penataan fungsi pendidikan Islam harus dilakukan, terutama pada sistem pendidikan persekolahan harus diupayakan secara terus menerus, berkesinambungan, berkelanjutan, sehingga usahanya dapat menjangkau pada perluasan dan pengembangan sistem pendidikan Islam luar sekolah. Harus dilakukan inovasi kelembagaan dan tenaga kependidikan. Tenaga kependidikan harus ditingkatkan etos kerja dan profesionalismenya. Perbaikan pada aspek materi [kurikulum], pendekatan, dan metodologi yang masih berorientasi pada sistem tradisional, perbaikan pada aspek manajemen pendidikan itu sendiri. Tetapi usaha melakukan inovasi tidak hanya sekedar tanbal sulam, tetapi harus secara mendasar dan menyeluruh, mulai dari fungsi, tujuan, metode, strategi, materi [kurikulum], lembaga pendidikan, dan pengelolaannya. Dengan kata lain, penataan pendidikan Islam haruslah bersifat komprehensif dan menyeluruh, baik pada tingkat konsep maupun penyelenggaraan; tidak lagi adhoc dan incremental seperti sering terjadi di masa silam (Azyumardi Azra, 2002 :17). Penataan fungsi pendidikan Islam, tentu dengan memperhatikan dunia kerja, sebab dunia kerja mempunyai andil dan rentang waktu yang cukup besar dalam jangka kehidupan pribadi dan kolektif.

Dari gambaran tersebut di atas, tanpaknya kita perlu menyusun langkah-langkah strategi sebagai upaya untuk kembali membangkitkan dan menempatkan pendidikan Islam pada peran yang semestinya dengan berusaha menata ulang paradigma pendidikan Islam sehingga pendidikan Islam kembali bersifat aktifprogresif. Langkah-langkah strategi tersebut diantaranya, yaitu : Pertama, landasan filosofis dan terori, visi dan misi pendidikan, harus dikembangkan dan dijabarkan atas konsep dasar kebutuhanan manusia. Perlu menempatkan kembali seluruh aktivitas pendidikan di bawah "kerangka dasar kerja spritual". Seluruh aktivitas intelektual dan proses pendidikan senantiasa dilandasi oleh nilai-nilai agama, di mana tujuan akhir dari seluruh aktivitas pendidikan sebagai upaya menegakkan ajaran agama dengan memanusiakan manusia dalam konteks kehidupannya. Kedua, perlu ada perimbangan [balancing] antara disiplin atau kajian-kajian agama dengan pengembangan intelektualitas dalam program kurikulum pendidikan. Sistem pendidikan Islam harus menganut integrated curriculum, artinya perpaduan, koordinasi, harmonis, dan kebulatan materi-materi pendidikan dengan ajaran Islam, dan bukan separated subject curriculum maunpun correlated curriculum (S. Nasution, 1990 : 162). Maka dengan konsep integrated curriculum, proses pendidikan akan 
memberikan penyeimbangan antara kajian-kajian agama dengan kajian lain [non-agama] dalam pendidikan Islam yang merupakan suatu keharusan, apabila menginginkan pendidikan Islam kembali survive di tengah perubahan masyarakat. Ketiga, perlu dikembangkan pendidikan yang berwawasan kebebasan, sehingga insan akademik dapat melakukan pengembangan keilmuan secara maksimal. Kenapa demikian, karena selama masa kemunduran Islam, telah tercipta stigma dengan dikondisikan banyak sekat dan wilayah terlarang bagi perdebatan, perbedaan pandapat dan pandangan yang mengakibatkan sempitnya wilayah pengembangan intelektual rasional. Kesempatan berijtihad yang selama ini di anggap tertutup juga menjadi malapetaka bagi perkembangan pemikiran "rasional intelektual" dan ikut terkubur. Kita tidak mempunyai ruang bebas untuk mengekspresikan pemikiran, pandangan, dan gagasan. Apabila muncul pemikiran baru yang berbeda dengan mainstream, sering kali dianggap sebagai pengkaburan, penyesetan dan penyimpangan dari agama dan kadang kala, kritik terhadapan pandangan dan pemikiran keagamaanpun dianggap sebagai kritik terhadap otoritas Tuhan, nabi dan lain-lain. Agama kemudian dijadikan sebagai otoritas baru untuk memasung dan mengkerdilkan [membonsai] pemikiran-pemikiran inovatif yang muncul. Maka, dengan upaya menghilkangkan atau minimal membuka kembali sekat dan wilayahwilayah yang selama ini terlarang bagi perdebatan dan kajian, akan menjadikan wilayah pengembangan intelektual semakin luas yang tentu membuka peluang lebar bagi pengembangan keilmuan di dunia pendidikan Islam pada khususnya dan Islam pada umumnya. Keempat, mulai melakukan strategi pendidikan yang membumi pada kebutuhan nyata masyarakat yang akan menghartar peserta didik pada kebutuhan akhirat. Mengembangkan pendidikan Islam berwawasan kebudya dan masyarakat, pendidikan yang berwawasan kebebasan dan demokrasi, pendidikan yang menyenangkan dan mencerdaskan. Diperlukan pendidikan yang menghidupkan kembali tradisi intelektual yang bebas, dialogis, inovatif, dan kreatif. Ibnu Rushd, menyatakan bahwa hikmah, penalaran, dan filsafat adalah sahabat agama [syariah], dan saudara sesunya. Agama dan kebebasan berpikir merupakan dua mata uang logam yang tidak dapat dipisahkan (Zuhairini Miswari, 2003). Dari pandangan ini kebebasan berpikir mutlak diperlukan untuk melahirkan intelektualintelektual yang memiliki pandangan keagamaan yang baru, segar, dan jernih. Kita berharap disain pendidikan Islam pada era informasi, era globalisasi, menjadi era berhembusnya kebebasan berpikir, sehingga mendorong lahirnya pemikir-pemikir keagamaan yang 
memiliki kemampuan bersaing, kritis, transformatif, inovatif, dan konstruktif dalam menghadapi tantang perubahan.

\section{Menuju Pendidikan Islam Bermutu dan Unggul}

Mutu pendidikan merupakan hal yang harus diperhatikan dan diupayakan untuk dicapai. Sebab pendidikan akan menjadi siasia bila mutu proses dan lulusannya rendah, tidak terbangun jiwa kemandirian dan kreatifitasnya. Lebih parah dan menyedihkan lagi jika out put pendidikannya menambah beban masyarakat, keluarga, dan negaranya (Ahmad Baharuddin, 2007: 129). Saat sekarang ini, ada keinginan dari masyarakat dan berbagai lembaga pendidikan Islam untuk menjadikan pendidikan Islam sebagai salah satu pendidikan alternatif. Tetapi pemikiran ini memerlukan paradigma baru untuk meningkatkan kualitan pendidikannya. Pertanyaannya, pendidikan Islam yang mutu dan unggul yang bagaimana? Apakah kita harus memperbaiki secara radikal terhadap kelemahankelemahan pendidikan Islam yang telah diproyeksikan oleh A. Mukti Ali, bahwa kelemahan pendidikan Islam dewasa ini, disebabkan oleh faktor penguasaan sistem dan metode, bahasa sebagai alat untuk memperkaya persepsi, dan ketajaman interpretasi [insight], kelemahan kelembagaan [organisasi], kelemahan ilmu dan teknologi. Apabila hal ini menjadi fokus, maka pendidikan Islam harus didesak untuk melakukan inovasi, tidak hanya terkait dengan kurikulum dan perangkat manajemen, tetapi juga strategi dan taktik operasional dan metodologinya. Strategi dan taktik itu, bahkan sampai menuntut perombakan model-model sampai dengan institusi-institusinya sehingga lebih efektif dan efisien, dalam arti paedagogis, sosiologis, dan cultural dalam menunjukkan perannya (H.M.Arifin, 1991: 3), untuk mewujudkan pendidikan Islam yang bermutu dan unggul.

Berbicara tentang pendidikan yang mutu dan unggul, tentu saja harus didasarkan pada suatu standar dan ukuran kemajuan [benchmark] tertentu yang terbuka [accountable], sehingga publik dengan mudah mengikuti dan menilai kemajuan pendidikan yang ada (Ade Cahyana, 2006). Apakah pendidikan yang bermutu dan unggul dapat dilihat dari lulusan dengan nilai tinggi atau dilihat dari lulusannya dapat diserap pasar dengan cepat, ataukah dinilai oleh Badang Akreditasi Nasional [BAN] dengan predikat terakreditasi dengan nilai A, B, dan C atau tidak terakreditas (Hujair AH. Sanaky, 2006: 409), atau memiliki guru dan dosen yang tersertifikasi dengan memiliki kompetensi untuk mengajar. Apakah pendidikan bermutu 
dan unggul dilihat dari sisi gedung [fisiknya], manajemennya, atau kedua-duanya? Apakah manusianya, dilihat manusia seperti apa yang dianggap mutu, unggul, dan profesional dalam bidang apa. Ada sebgaina orang justru mencurigai motto "pendidikan unggulan" ini dengan mensinyalir sebagai bentuk kafitalisasi dan komersialisasi, di mana dimensi fisik, materi, bangunan, lebih dikedepankan dari pada "isi", proses atau substansi pendidikan itu sendiri. Pendidikan mutu dan unggul, apakah dilihat dari output-nya, dilihat dari nilai yang diperoleh para lulusannya. Pertanyaan lulusan berkualitas seperti apa yang dianggap mutu dan unggul? Misalnya saja para siswa dan sarjana yang lulus dengan nilai tinggi, apakah ada korelasi signifikansinya dengan kemandirian atau keistimewaan yang akan mereka dapatkan? Realitas menunjukkan banyak siswa lulus SLTA memiliki nilai tinggi, tapi tidak dapat meneruskan ke perguruan tinggi, karena disebabkan oleh biaya, orang tua tidak mampu. Sarjana lulus dengan nilai tinggi, ujung-ujungnya menjadi buruh/pedagang, pengangguran, lantaran tidak memiliki koneksi, walaupun hal yang ditekuni dan dikerjakan memang tidak salah, tetapi tidak macht atau mismacht dengan pendidikan yang ditekuni. Inilah kondisi yang dihadapi pendidikan di negeri ini.

Selain itu, manusia unggul seperti apa yang dikehendari dari prodak pendidikan, karena bukan sekedar pendidikan yang unggulan. Dalam konteks historis, manusia yang dapat dijadikan teladan adalah menusia yang dikategori unggulan bukanlah sematamata ditentukan lembaga pendidikan yang membesarkannya, malahan lebih banyak dihasilkan oleh keluarga atau masyarakat yang mengelilinginya. Lembaga pendidikan pesantren, biayanya murah, santri banyak yang gratis, dianggap tradisonal, tetapi banyak melaihrkan para pahlawan, para tokoh pemikir bangsa. Maka dalam konteks ini, proses pendidikan di pesantren lebih berlaku dan faktor utamanya adalah keteladanan, kesungguhan, kerendahan hati, kesederhanaan, keikhlasan, yang dibangun oleh kiai dan para gurunya dalam proses, tetapi nilai-nilai ini pada zaman sekarang lebih mendapatkan respons yang kurang baik.

Dari sekian pertanyaan di atas, dapat dikatakan bahwa pendidikan yang bermutu dan unggul adalah memiliki visi, misi, dan tujuan yang jelas, memiliki program pendidikan dan pembelajaran yang berorientasi pada kebutuhan masyarakat, inovatif dan pengembangan ilmu dan teknologi, memiliki sumberdaya yang profesional, memiliki manajemen yang profesional dan bertanggungjawab. Lulusannya memiliki standar kompetensi pengetahuan [knowledge] kognitif yang memadai, memiliki kemampuani afektif yang anggun, yaitu memiliki 
kepribadian dan moral yang tinggi, jujur, bertanggungjawan, dan bersamangat untuk melakukan inovasi, memiliki kemampuan psikomotorik yang tinggi, memiliki skill untuk menjawab kabutuhan masyarakat, melakukan kegiatan secara terampil, dan memiliki kemampuan bertindak yaitu menghasilkan sesuatu yang konkrit dan menghasilkan jasa, serta dapat diserap pasar atau pengguna pendidikan. Dengan dasar ini, maka pendidikan Islam perlu membangun sistem pendidikan yang mampu mengembangkan sumber daya manusia yang berkualitas, dilandasai dengan nilainilai ilahiyah, kemanusian [insaniyah], lingkungan dan berbudaya, manajemen pendidikan dengan berorientasi pada profesionalisme dan mutu, menyerap aspirasi dan mendayagunakan potensi masyarakat, berorientasi pada otonomi, meningkatkan demokratisasi penyenggaraan pendidikan, serta memenuhi permintaan perubahan arus globalisasi. Katakan saja, konsep hasil belajar yang lebih baik tentu saja berorientasi pada kemampuan kognitif, psikomotorik, afektik, dan tindakan. Kemampuan bertindak terkait erat dengan pendidikan life skills (Suharsimi Arikunto, 2008), artinya ketika lulusan dari satuan pendidikan Islam, sudah memiliki pengalaman yang cukup memadai dari kehidupan pendidikannya untuk melakukan sesuatu di masyarakat, yaitu berkewajiban mencari, menemukan dan memanfaatkan ilmu bagi keperluan kehidupan umat manusia, sekaligus juga harus bertanggungjawab atas apa yang terjadi selanjutnya jika dengan ilmu itu menimbulkan kerusakan lingkngan (Syamsul Ma'arif, 2007: 122).

Dalam kerangka ini, menurut penulis pendidikan Islam harus berupaya untuk: Pertama, mengembangkan konsep pendidikan integralistik, yaitu pendidikan secara utuh yang berorientasi pada Ketuhanan, kemanusiaan dan alam pada umumnya sebagai suatu yang integralistik bagi perwujudan kehidupan yang rahmatan lil 'alamin. Kedua, mengembangkan konsep pendidikan huhanistik, yaitu pendidikan yang berorieintasi dan memandang manusia sebagai manusia [humanisasi] dengan menghargai hah-hak asasi manusia, hak untuk menyuarakan pendapat walaupun berbeda, mengembangkan potensi berpikir, berkemauan dan bertindak sesuai dengan nilai-nilai luhur kemanusiaan. Ketiga, mengembangkan konsep pendidikan pragmatis, yaitu memandang manusia sebagai makhluk yang selalu membutuhkan sesuatu untuk melangsungkan, mempertahankan dan mengembangkan hidupnya baik jasmani maupun rohani dan mewujudkan manusia yang sadar akan kebutuhan-kebutuhan hidupnya dan peka terhadap masalah-masalah kemanusiaan. Keempat, mengembangkan konsep pendidikan yang berakar pada 
budaya yang akan dapat mewujudkan manusia yang mempunyai kepribadiaan, harga diri, percaya pada kemampuan sendiri, membangun budaya berdasarkan budaya sendiri dan berdasarkan nilai-nilai ilahiyah. Secara umum, konsep pendidikan Islam yang ditawarkan adalah pendidikan yang berorientasi pada kompetensi nilai-nilai ilahiyah, knowledge, skill, ability, social-kultural dan harus berfungsi untuk memberikan kaitan secara operasional antara peserta didik dengan masyarakatnya, lingkungan sosial-kulturalnya, dan selalu menerima dan ikut serta melakukan perubahan (Hujair AH. Sanaky, 2003: 301).

Mungkin saja, kita perlu mencermati pendidikan alternatif yang dimotori oleh SLTP Qoryah Toyyibah dibangun oleh Ahmad Baharuddin, yang merupakan salah satu bentuk sekolah alternatif yang terbukti mampu memberikan terapi terhadap kondisi "akut" pendidikan nasional selama ini. Bebarapa hal yang perlu dicermati adalah: Pertama, SLTP ini menekankan goals setting pada basis potensi anak dengan memberikan kebebasan intelegensi anak. Artinya, sejak masuk setiap anak diberikan kebebasan ruang kreatifitas, serta wadah akses yang sangat optimal, dan Kedua, pembedayaan dengan prinsip menciptakan sekolah murah dan bermutu, maka ada dua pilar pendidikan utama dari jalur alternatif pendidikan anak didik di SLTP Qoryah Tayyibah, yaitu basis orientasi yang independen oleh lembaga maupun anak didik, dan implementasi pengembangan potensi intelegia anak dengan ketulusan mencerdaskan anak didik yang "beyond" atas kondisi ekonomi masyarakat (Ahmad Baharuddin, 2007: 7).

Konsep pendidikan yang dikembangkan pada SLTP Qoryah Tayyibah adalah menggunakan prinsip-prinsip dasar pendidikan komunitas, yaitu: Pertama, membebaskan, dalam proses pendidikan selalu dilandasi dengan semangat membebaskan, dan semangat perubahan kearah yang lebih baik. Terjemahan konsep membebaskan disini adalah keluar dari belunggu legal formalistik yang selama ini menjadikan pendidikan tidak kritis, dan tidak kreatif, sedangkan semangat perubahan lebih diartikan pada kesatuan proses pembelajaran. Kedua, keberpihakan, adalah ideologi pendidikan itu sendiri, di mana pendidikan dan pengetahuan hak bagi seluruh warga. Ketiga, partisifatif, artinya dalam proses mengutamakan prinsip partisifasi antara pengelola, murid, keluarga, serta masyarakat dalam merancang bangun sistem pendidikan yang sesuai kebutuhan. Keempat, kurikulum berbasis kebutuhan, artinya desain kurikulum terkait dengan sumberdaya lokal yang tersedia, sehingga belajar adalah baigaimana menjawab kebutuhan akan 
pengelolaan sekaligus penguatan daya dukung sumberdaya yang tersedia untuk menjaga kelestarian serta memperbaiki kehidupan. Kelima, kerjasama, artinya metodologi pembelajaran yang dibangun selalu berdasarkan kerjasama dalam dalam proses pembelajaran. Tidak perlu ada lagi sekat-sekat dalam proses pembelajaran, juga tidak perlu ada dikotomi guru dan murid, semuanya adalah murid [orang yang berkemauan belajar], semuanya adalah tim yang berproses secara partisipatif, maka kerjasama dari antar individu berkembang ke antar kelompok, antar daerah, antar negara, antar benua, dan antar semuanya. Keenam, sistem evaluasi berpusat pada subjek didik, artinya puncak keberhasilan pembelajaran adalah ketika si subjek didik menemukan dirinya, berkemampuan mengevaluasi diri sehingga tahu persis potensi yang dimilikinya, dan berikut mengembangkannya sehingga bermanfaat bagi yang lain. Ketujuh, percaya diri, pengakuan atas keberhasilan bergantung pada subjek pembelajar itu sendiri. Pengakuan dalam bentuk apa pun [termasuk ijasah] tidak perlu dicari, karena pengakuan akan datang dengan sendirinya manakalah kapasitas pribadi dari si subjek didik meningkat, dan bermanfaat bagi yang lain (Ahmad Baharuddin, 2007: 14-15).

Dari semua dipaparkan di atas, kita harus berani menata dan mendesain ulang model pendidikan Islam yang berkualitas dan bermutu, dengan merumuskan visi, misi, serta tujuan yang jelas, kurikulum, dan meteri pembelajaran yang diorientasikan pada kebutuhan peserta didik dan kebutuhan masyarakat untuk dapat menjawab tantangan perubahan, metode pembelajaran diorientasikan kepada upaya mencari dan mecahkan masalah yang berorientasi pada "menjadi", dan bukan didominasi oleh model ceramah yang berorientasi pada hanya "memiliki". Oleh karena itu, membangun jiwa kemandirian, kreativitas, kepekaan sosial, dan keberanian berpikir untuk menghadapi realitas kehidupan harus dikembang dalam proses pendidikan. Kata Ahmad Baharuddin, pendidikan dan pembelajaran berbasis "kebutuhan", sehingga puncak keberhasilan pembelajaran adalah ketika pembelajar menemukan sendiri, berkemampuan mengevaluasi diri sendiri, sehingga pembelajar tahu persis potensi yang dimilikinya (Ahmad Bahruddin, 2007: 13 , 30). Dengan demikian, penilaian terhadap mutu dan unggul suatu pendidikan tidak perlu direkayasa dan diformalkan, tetapi akan datang dengan sendirinya dari masyarakat pengguna. 


\section{Kesimpulan}

Kata akhir, pendidikan yang bermutu dan unggul merupakan hal yang harus diperhatikan dan diupayakan untuk dicapai. Pendidikan akan menjadi sia-sia apabila mutu proses dan lulusannya rendah. Penilaian dan pengakuan terhadap pendidikan yang mutu dan unggul atau tidak, akan lebih banyak di tentukan oleh masyarakat profesional. Dengan kata lain, bahwa masyarakat profesional yang akan menjadi penilai [quality control] dari lembaga pendidikan yang ada. Kontrol dilakukan dari kemampuan para lulusan lembaga pendidikan tersebut, dengan program-program pembelajarannya, dosen dan guru di nilai oleh masyarakat (Onno W. Purbo, 2003). Maka, pendidikan Islam berusaha melakukan penataan terhadap program-program pendidikannya agar mencapai standar mutu dan unggul yaitu lulusannya memiliki kompetensi pengetahuan yang memadai, memiliki afektif yang anggun, memiliki skill untuk dapat menjawab kabutuhan masyarakat, dan dapat diserap oleh pengguna pendidikan, apabila tidak maka akan menjadi sia-sia, bila mutu proses dan lulusannya rendah.

\section{DAFTAR PUSTAKA}

Arifin, H.M., 1991, Kapita Selekta Pendidikan, Bina Aksara, Jakarta.

Arikunto, Suharsimi, 2008, Swot dan Desain Kurikulum Pendidikan Islam MSI UII, Makalah, Disampaikan dalam Workshop Kurikulum Ekonomi Islam dan Pendidikan Islam Program Pascasarjana [S-2] Magister Studi Islam Universitas Islam Indonesia, Senin, 16 Juni 2008.

Azra, Azyumardi, 2002, Paradigma Baru Pendidikan Nasional, Rekonstruksi dan Demokratisasi, Penerbit Buku Kompas, Jakarta.

Aziz Abdul, [Direktur Madrasah dan Pendidikan Agama pada Sekolah Umum Departemen Agama], Perlu Peraturan Pemerintah tentang Desentralisasi Madrasah, Kompas, Jakarta, From: http:/ /www. kompas.com/kompas-cetak/0211/26/DIKBUD/808.htm, accses, sabtu, 16 April 2005, jam 15.30

Baharuddin, Ahmad, 2007, Pendidikan Alternatif Qaryah Thayyibah, LKiS, Yogyakarta.

Cahyana, Ade, Indonesia 2010: Merubah Mitos menjadi Realitas Pembangunan, From: http://www.depdiknas.go.id/ Jurnal/26/ 
indonesia_2010_Ade_Cahyana.htm, accses, Sabtu, 16/9/2006, jam. 13.10.

Dahriman, Ciput MSA M, dan Mahfudh Djunaidi, Berlaku Adil terhadap Madrasah, From: http://www. suaramerdeka. com/ harian/0211/12/kha1.htm, accses, Sabtu, 16 april 2005, jam 15.30

Ma'arif, Syamsul, 2007, Revitalisasi Pendidikan Islam, Graha Ilmu, Yogyakarta.

Mastuhu, 2003, Menata Ulang Pemikiran Sistem Pendidikan Nasional dalam Abad 21, Safiria Insania Press dan MSI, Yogyakarta.

Miswari, Zuhairini, 2003, Islam dan Kebebasan Berpikir, Form:http://www, polarhome. com/pipermail/karawang/2003January/000318.html. akses, 14/10/2003

Nasution, S.,1990, Asas-Asas Kurikulum, Penerbit Jemmars, Bandung.

Proposal Jurnal Pendidikan Islam: Peningkatan Mutu Pendidikan Islam, Fakultas Ilmu Agama Islam, Jurusan Tarbiyah, Universitas Islam Indonesia, Yogyakarta, 15 April 2008.

Purbo, Onno W., Tantangan bagi Pendidikan Indonesia, From: http:// bebas. vlsm.org/v09/onno-ind-1/application/ education/ tantangan-bagi-pendidikan-indonesia-08-1998.rtf, accses, Jum'at, 7/11/2003.

Sanaky, Hujair AH.,2003,Paradigma Pendidikan Islam: Membangun Masyarakat Madani Indonesia, Safiria Insania Press dan MSI, Yogyakarta.

, 2006, Paradigma Pembangunan Pendidikan di Indonesia Pasca Reformasi antara Mitos dan Realitas, dalam Jurnal Ilmuilmu Sosial Unisia, No.62/XXIX/IV/2006, Terakreditasi SK Dikti No.459/D3/T/2003, ISSN:0215-1412, Universitas Islam Indonesia, Yogyakaarta.

Soeroyo, 1991, Berbagai Persoalan Pendidikan, Pendidikan Nasional dan Pendidikan Islam di Indonesia, Jurnal Ilmu Pendidikan Islam, Problem dan Prospeknya, Volume I, Fak. Tarbiyah IAIN Suka, Yogyakarta.

Tilaar, H.A.R., 1991, Sistem Pendidikan Nasional yang Kondusif Bagi Pembangunan Masyarakat Industri Modern Berdasarkan Pancasila, Makalah Utama Kongres Ilmu Pengetahuan Nasional $\mathrm{V}$

Usa, Muslih, 1991, Pendidikan Islam di Indonesia, Antara Cita dan Fakta [Suatu Pengantar],Tiara Wacana, Yogyakarta. 